\title{
KLINIK PEMASARAN DIGITAL BAGI DOSEN BERWIRAUSAHA
}

\author{
Alin Liana1), Sulfaidah"2), Maisya Zahra AI Banna') \\ 1)Program Studi Pendidikan Biologi, STKIP Pembangunan Indonesia, Gowa, Sulawesi Selatan, Indonesia \\ 2)Program Studi Pendidikan Ekonomi, STKIP Pembangunan Indonesia, Gowa, Sulawesi Selatan, Indonesia \\ Corresponding author : Maisya Zahra Al Banna \\ E-mail : maisyazahra.mz@gmail.com
}

Diterima 27 Maret 2021, Direvisi 08 April 2021, Disetujui 08 April 2021

\begin{abstract}
ABSTRAK
Pemasaran digital merupakan strategi promosi produk barang dan jasa dengan memanfaatkan media digital yang terintegrasi pada perangkat elektronik dan menggunakan koneksi jaringan internet. Terdapat $6 \%$ dosen STKIP Pembangunan Indonesia mengelola usaha mikro secara mandiri, yang bergerak dalam bidang kuliner, kosmetik, pakaian, pemanfaatan sagu, budidaya tanaman dan usaha pengolahan limbah plastik. Usaha mikro yang digeluti oleh dosen masih cenderung konvensional, dan belum memanfaatkan peluang digitalisasi dalam pemasaran produknya, sehingga perlu dilakukan pelatihan pemasaran digital untuk mengimbangi besarnya tantangan persaingan usaha saat ini. Kegiatan ini dibagi menjadi dua tahap, tahap pertama merupakan pemberian materi marketing digital yang terdiri atas (i) pemanfaatan website dan media sosial sebagai media promosi produk, (ii) penguasaan teknik dasar iklan, dan (iii) pemanfaatan video untuk iklan. Sedangkan tahap kedua merupakan praktek pemanfaatan web atau media sosial oleh peserta untuk mempromosikan produk yang dijual. Dari hasil pelatihan ini seluruh peserta dapat menerapkan pemasaran digital dalam mempromosikan produk yang dijual, dan terdapat satu orang peserta yang telah berhasil memanfaatkan video promosi untuk meningkatkan jumlah produk yang terjual. Kepuasan peserta terhadap pelatihan diukur menggunakan kuesioner, yang menunjukkan bahwa $88 \%$ peserta menyatakan puas terhadap pelatihan ini.
\end{abstract}

Kata kunci: pemasaran digital; dosen; STKIP Pembangunan Indonesia.

\begin{abstract}
Digital marketing is a strategy to promoting goods and services products by utilizing digital media integrated in electronic devices and using internet network connections. There are $6 \%$ lecturers of STKIP Pembangunan Indonesia managing micro businesses independently, engaged in culinary, cosmetics, clothing, sago, decorative plants and plastic waste treatment business. Micro businesses pursued by lecturers still tend to be conventional, and have not taken advantage of digitalization opportunities in the marketing of their products, so it is necessary to conduct digital marketing training to offset the magnitude of the challenges of business competition today. This activity is divided into two stages, the first stage is the provision of digital marketing materials consisting of (i) the utilization of websites and social media as a product promotional media, (ii) mastery of basic advertising techniques, and (iii) the utilization of video for advertising. While the second stage is the practice of using the web or social media by participants to promote the products sold. From the results of this training all participants can apply digital marketing in promoting their products, and there is one participant who has successfully utilized the promotional video to increase the number of products sold. Participants' satisfaction with the training was measured using a questionnaire, which showed that $88 \%$ of participants expressed satisfaction with the training.
\end{abstract}

Keywords: digital marketing; lecturer; STKIP Pembangunan Indonesia.

\section{PENDAHULUAN}

STKIP Pembangunan Indonesia merupakan salah satu perguruan tinggi swasta yang memiliki rencana strategis membangun inkubator usaha mikro yang berorientasi dalam mengembangkan dan menumbuhkan jiwa kewirausahaan bagi mahasiswa. Untuk memperpendek jarak antara program pengembangan kewirausahaan dengan sumber daya manusia yang dimiliki STKIP Pembangunan Indonesia, maka perlu dilakukan beberapa strategi pencapaian melalui peningkatan kapasitas dosen dalam berwirausaha. Hal ini dimaksudkan agar dosen mampu memberikan contoh nyata kewirausahaan sekaligus memotivasi mahasiswa agar menjadi SDM yang unggul dan mandiri di kemudian hari. 
Berdasarkan hasil pendataan diketahui bahwa terdapat $6 \%$ dosen dalam lingkup STKIP Pembangunan Indonesia yang menjalankan usaha skala mikro. Adapun jenis usaha yang digeluti amat beragam, mulai dari usaha kuliner, pakaian, pemanfaatan sagu asli, budidaya tanaman, serta pengolahan limbah plastik. Terdapat pula dosen pemilik usaha yang mempekerjakan mahasiswa sebagai karyawan untuk bekerja paruh waktu. Hampir $50 \%$ mahasiswa STKIP Pembangunan bekerja paruh waktu untuk membiaya kuliah dan menghidupi diri secara mandiri. Usaha mikro yang dimiliki oleh dosen masih tergolong baru, yang ditunjukkan dengan rendahnya waktu pengoperasian usaha, serta promosi yang cenderung konvensional, dimana masih mengandalkan informasi perorangan.

Persaingan usaha masa kini tidak dapat berkembang tanpa ditunjang oleh kemampuan pelaku usaha dalam menciptakan pembaruan. Selain persaingan, kemampuan pelaku usaha dalam menerapkan strategi pemasaran berupa promosi produk turut andil mempengaruhi keberlanjutan usaha. Promosi produk secara konvensional dinilai tidak banyak membantu mendongkrak angka penjualan produk.

Promosi didefinisikan sebagai bentuk strategi penjualan dengan melibatkan teknik informasi persuasif terhadap pihak yang mempengaruhi pembelian. Penelitian mengenai strategi promosi produk UKM eks lokalisasi Dolly Surabaya menunjukkan bahwa kekuatan promosi menggunakan personal selling anggota UKM turut mempengaruhi penjualan produk (Reswana, 2015).

Meskipun sebagian besar peserta memiliki latar belakang usaha yang berbedabeda, dan masih tergolong baru dalam kegiatan kewirausahaan, maka penentuan strategi pemasaran yang tepat bagi dosen pemilik usaha perlu dilakukan. Seiring dengan era digilitasasi maka perlu diberikan pula pelatihan strategi pemasaran produk berbasis digital agar usaha mikro yang dirintis dosen tetap bertahan di tengah persaingan yang semakin ketat.

Perkembangan teknologi digital memungkinkan para pelaku usaha dapat memasarkan produk secara online, serta melakukan transaksi perbankan secara online pula (Wardhana, 2015). Berbeda dengan usaha ritel yang menerapkan sistem offline, penjualan online tidak dikenakan kewajiban membayar pajak, serta perizinan yang relatif lebih cepat dan murah. Penerapan pemasaran digital sebagai strategi pemasaran berpengaruh pula terhadap peningkatan omset penjualan, jumlah pembeli serta kepuasan konsumen (Afrilia,
2018; Hapsoro et al., 2019; Saputra \& Ardani, 2020).

Pemasaran online merupakan komponen dari electronic commerce (ecommerce) yang berfokus kepada pelaku pasar. Diantara beberapa kelebihan yang dimiliki, pemasaran online memiliki kekurangan, di antaranya adalah munculnya kekhawatiran pembeli ketika akan melakukan pembayaran, transaksi melibatkan transfer antar Bank, target market didominasi oleh usia muda sedangkan usia diatas 45 tahun hanya sedikit yang memutuskan membeli produk secara online (Malik \& Mulyono, 2017; Sarastuti, 2017; Saraswati, 2017).

Mencermati keuntungan yang dimiliki oleh pemasaran digital, melalui kegiatan ini dosen pemilik usaha akan diberikan pelatihan penerapan pemasaran digital dengan memanfaatkan fitur website (web), Google Ads dan aplikasi promosi produk berbasis media sosial dan komunitas online.

\section{METODE}

Kegiatan klinik pemasaran digital diselenggarakan pada bulan Agustus 2020, dengan mengikutsertakan 19 orang dosen STKIP Pembangunan Indonesia yang tercatat memiliki usaha mandiri dan telah beroperasi minimal tiga bulan. Kegiatan ini terlaksanan melalui dua tahap, yaitu tahap I berisi pembekalan materi oleh penggiat pemasaran digital, dan tahap II adalah praktik pemasaran digital oleh peserta kegiatan.

\section{Tahap 1: Pembekalan Materi}

Adapun materi yang diberikan kepada peserta adalah (i) pemanfaatan web dan media sosial dalam penjualan produk, (ii) teknik penguasaan dasar iklan, dan (iii) penggunaan video untuk iklan. Dalam pelaksanaannya seluruh kegiatan diterapkan dengan menggunakan metode ceramah, serta diskusi oleh fasilitator penggiat pemasaraan digital.

\section{Tahap 2: Evaluasi Kegiatan}

Pada tahapan ini peserta diberikan waktu selama empat pekan untuk menerapkan pemasaran digital secara sederhana, menggunakan media sosial. Dalam tahapan ini pula, dilakukan pengukuran kepuasan peserta terhadap kualitas pelatihan yang diikuti. Pengukuran kepuasan peserta diukur berdasarkan rumus Kirkpatrick. Kriteria penilaian hasil pembobotan untuk level reaksi dihitung dengan menggunakan rumus pembobotan Kirkpatrick (Nurhayati, 2018) :

$$
\mathrm{X}=\frac{\text { total nilai jawaban responden item } \mathrm{ke}-\mathrm{i}}{\text { nilai tertinggi } \times \text { jumlah responden }}
$$


Tabel 1. Kriteria Penilaian

\begin{tabular}{cl}
\hline Kisaran Nilai & \multicolumn{1}{c}{ Interpretasi } \\
\hline$<50 \%$ & $\begin{array}{l}\text { Peserta menunjukkan } \\
\text { reaksi kurang baik } \\
\text { terhadap penilaian }\end{array}$ \\
\hline $50-60 \%$ & $\begin{array}{l}\text { Peserta menunjukkan } \\
\text { reaksi yang lebih baik } \\
\text { terhadap pelatihan }\end{array}$ \\
\hline $61-80 \%$ & $\begin{array}{l}\text { Peserta menunjukkan } \\
\text { reaksi yang positif karena } \\
\text { menyadari mendapat } \\
\\
\text { masukan yang berguna } \\
\text { selama pelatihan }\end{array}$ \\
\hline $81-100 \%$ & $\begin{array}{l}\text { Peserta menunjukkan } \\
\text { reaksi positif yang tinggi } \\
\text { terhadap penilaian }\end{array}$ \\
\hline
\end{tabular}

\section{HASIL DAN PEMBAHASAN}

Kegiatan

pelaksanaan

diselenggarakan selama satu hari penuh, dimulai pada pukul 09.00 - 15.00 WITA di STKIP Pembangunan Indonesia. Kegiatan dilakukan dengan metode ceramah, serta diskusi antara peserta dan fasilitator.

\section{Tahap 1 : Pembekalan Materi}

\section{Peran web dan media sosial sebagai media} promosi produk

Sebelum mulai menjalankan toko online, terdapat beberapa hal yang perlu dipertimbangkan oleh peserta, yaitu ketersediaan modal, produk yang akan dijual, target pasar yang akan disasar, strategi pemasaran dan kelangsungan bisnis online itu sendiri. Peserta dalam kegiatan ini telah mengetahui jenis produk serta target pasar yang akan disasar beserta dengan kesiapan modal untuk mengembangkan usaha yang dikelola. Melalui pelatihan ini peserta akan dibekali informasi mengenai strategi pemasaran dengan menggunakan web ataupun media sosial, sesuai dengan ketersedian modal yang dimiliki peserta.

Komponen utama dalam pemasaran digital di antaranya adalah ketersediaan perangkat komputer, kemampuan komunikasi serta muatan atau konten produk yang akan dipromosikan. Seluruh peserta dalam kegiatan ini telah mengetahui cara pengoperasian komputer, mampu mengkomunikasikan produk yang dimiliki, sekaligus melakukan promosi produk secara langsung. Sedangkan penggunaan web selama ini belum pernah dilakukan oleh peserta.

Pemanfaatan web mulai banyak digunakan oleh pelaku usaha, karena melalui sarana digital ini calon pembeli ataupun pelanggan lebih mudah mengakses produk yang dibutuhkan. Selain itu, web dapat digunakan pula dalam mengukur capaian penjualan barang pada target bulan tertentu. Adapun keuntungan dalam menggunakan web untuk pelaku usaha antara lain adalah memudahkan promosi dan pencarian informasi produk, memperluas aksesibilitas produk oleh siapa saja, memperluas pasaran produk sekaligus mendekatkan pelanggan, berperan sebagai wadah katalog yang berisi informasi produk yang disediakan, serta upaya dalam meningkatan pelayanan bagi pelanggan.

Keunggulan lain dari web adalah tampilan fitur yang lebih menarik. Beberapa fitur web yang dikenalkan melalui pelatihan ini adalah jenis produk atau layanan usaha yang ditawarkan, profil usaha untuk meningkatkan kepercayaan konsumen terhadap produk maupun pelaku usaha, kontak yang dapat dihubungi dengan mudah serta responsif, dan pengalaman konsumen yang telah mencoba produk atau testimoni. Keunggulan tersebut didukung pula oleh penelitian (Ayuni et al., 2019) yang menyimpulkan terdapat hubungan yang positif dan signifikan antara penggunaan media digital terhadap tingkat pejualan suatu produk. Semakin tinggi pemanfaatan media digital maka akan mempengaruhi tingkat penjualan produk yang dijual. Selain itu, keberadaan web dapat pula mempermudah dalam mengelola data barang, dan mempercepat proses pemesanan barang yang dilakukan oleh member, seperti hasil penelitian (Fauzi \& Aprilia, 2015) dan (Triyanto, 2017) mengenai penerapan sistem informasi pada penjualan produk berupa pakaian dan tas dari daerah pengrajin konveksi lokal. Sedangkan pada skala usaha yang lebih besar, pemanfaatan sistem informasi berbasis web dapat membantu pelaku usaha dalam melakukan seluruh proses bisnis, yang dimulai dari penjualan, pembuatan laporan, pengambilan keputusan, menghasilkan informasi meliputi tampilan data barang keseluruhan, laporan data berdasarkan kategori, laporan penjualan, sampai dengan laporan penjualan berdasarkan retur (Fitri et al., 2016). 


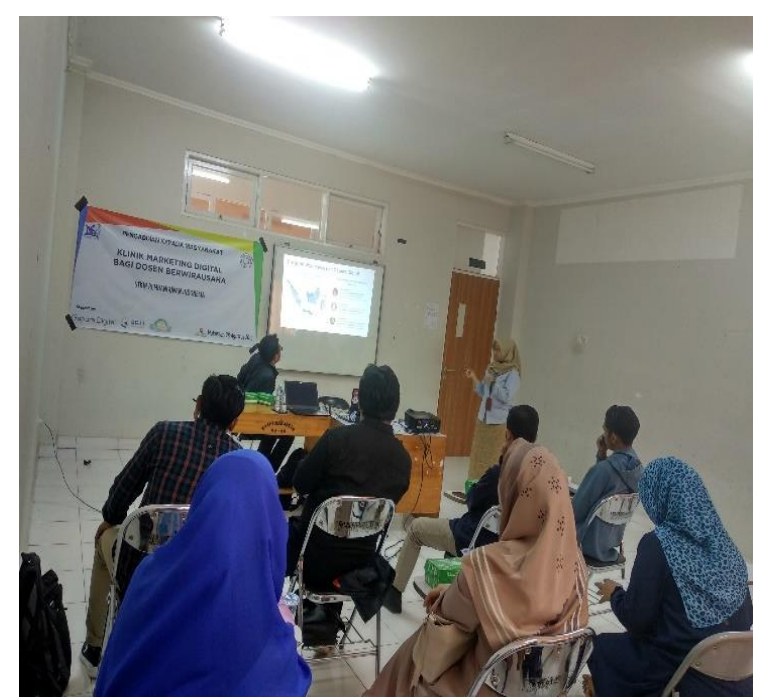

Gambar 1. Pemateri menyampaian materi penggunan web sebagai wadah promosi bagi dosen pemilik usaha.

Dalam pelatihan ini, peserta diperkenalkan teknik membuat web yang diawali dengan penentuan ide web, registrasi nama domain, pilihan web hosting, platform, dan rencana pengembangan web. Adapun tipe web yang umum digunakan adalah web $e-$ commerce yang menyerupai toko online, blog, web edukasi, dan web berita. Pemilihan tipe web ditentukan oleh kreativitas dan kemampuan pelaku usaha, tipe produk yang dijual, tipe konsumen yang disasar, serta kemudahan dalam mengakses produk. Melalui pelatihan ini, peserta dapat menentukan ide web yang cocok diterapkan pada jenis usaha yang dimiliki. Teknik pembuatan web bagi peserta tidak difasilitasi melalui kegiatan ini.

\section{Teknik penguasaan dasar iklan}

Komunikasi merupakan elemen utama tahapan pemasaran produk, karena memiliki empat peran utama dalam memberikan informasi kepada calon konsumen untuk mengetahui produk yang ditawarkan, mempengaruhi pilihan konsumen, memperkuat pengalaman konsumen terhadap keunggulan produk, dan membandingkan produk lain yang beredar di pasar, sehingga konsumen dapat memutuskan untuk membeli produk yang dijual (Sarastuti, 2017). Beberapa jenis promosi produk yang umumnya ditemui yaitu iklan, penjualan tatap muka, promosi penjualan, hubungan masyarakat dan publisitas, serta pemasaran langsung. Adapun keberhasilan komunikasi promosi ditentukan oleh kemampuan pemasar dalam menyampaikan pesan yang menarik dan efektif bagi konsumen, ketepatan memilih jenis promosi, ketepatan penggunaan media penyampaian pesan, daya tarik pesan dan kredibilitas sumber yang ditentukan dari tingkat kepercayaan konsumen (Lingkan, 2015).

Dalam pelatihan ini, peserta diberikan informasi mengenai teknik dasar pembuatan iklan, berupa cara menyusun iklan dengan baik, pemilihan kata yang mudah dipahami serta menarik minat masyarakat umum, lokasi pemasangan iklan, ukuran iklan yang digunakan, dan frekuensi pemasangan iklan. Selain pemasangan iklan secara online, peserta juga diberikan trik dalam memasang iklan secara offline melalui surat kabar karena pemasangan iklan pada media ini memiliki tingkat kesulitan tersendiri. Peserta harus dengan cermat memilih posisi pemasangan iklan yang paling tepat sehingga dapat menarik minat konsumen. Selain itu, frekuensi kemunculan iklan pada suatu media online maupun offline akan sangat mempengaruhi angka penjualan produk, dengan demikian jarak frekuensi pengulangan antar iklan harus diatur paling ideal adalah tujuh hari, hal ini dilakukan untuk menjaga momentum minat konsumen. Dalam bidang pemasaran, momentum adalah kunci keberhasilan penjualan produk.

\section{Pemanfaatan video untuk iklan}

Video telah banyak digunakan sebagai media promosi dalam pemasaran digital. Pembuatan konten video merupakan salah satu bentuk strategi pemasaran produk. Video dapat menyampaikan poin utama dari produk yang dijual secara efektif, sekaligus dapat mempengaruhi keputusan penonton untuk membeli produk. Beberapa jenis konten video yang cukup sering ditemukan adalah wawancara, monolog dan tutorial.

Melalui pelatihan ini, peserta diperkenalkan pada format iklan video yang tersedia dalam Google Ads. Google Ads merupakan fitur unggulan dari Google dan banyak dimanfaatkan dalam pengelolaan kampanye sebuah iklan. Pelaku usaha UMKM mulai memfokuskan promosi bisnis menggunakan fitur Google Ads, karena memiliki keunggulan berupa target penonton yang lebih spesifik, pengelolaan biaya lebih mudah, laporan lengkap, serta pemasangan iklan yang lebih optimal dengan menggunakan fitur yang tersedia pada produk Google tersebut. 


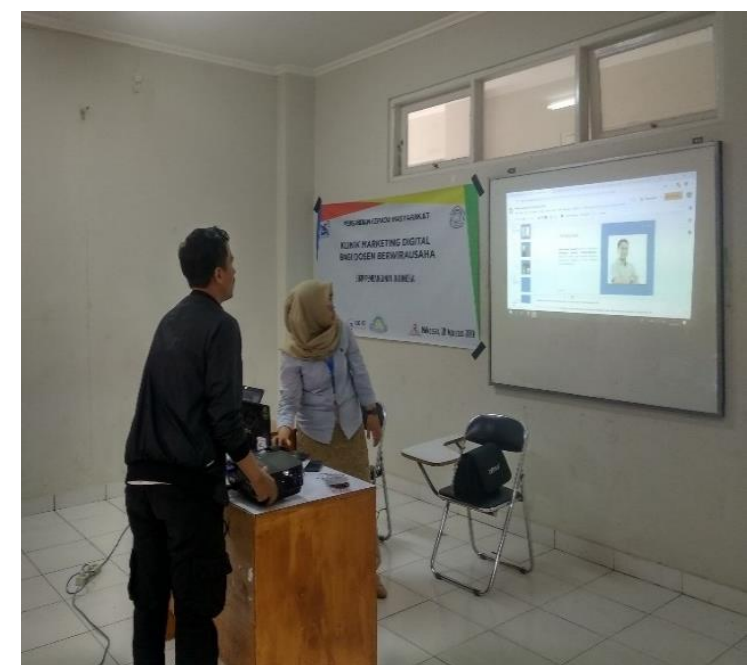

Gambar 2. Penggunaan Google Ads dalam promosi produk

Fitur yang ditawarkan oleh Google Ads antara lain adalah keyword planner, kompetitor ads, ads generator, dan related searches. Selain Google Ads, diperkenalkan pula pemasangan iklan pada aplikasi Youtube. Saat ini aplikasi YouTube merupakan aplikasi media yang paling popular di Indonesia. Data yang dirilis oleh Google pada tahun 2019 menunjukkan bahwa terdapat 50 juta pengguna aktif YouTube dari total 146 juta pengakses internet di Indonesia. Dengan demikian, lebih dari sepertiga pengguna internet di Indonesia aktif menggunakan YouTube. Aplikasi YouTube merupakan salah satu cara yang ampuh diterapkan pelaku usaha untuk menarik pelanggan melalui konten video.

Selain penguasaan komunikasi pemasaran, pelaku usaha penting untuk mengikuti perubahan perilaku konsumen sebagai dampak pemasaran 4.0. Saat ini sering ditemukan pemasaran viral melalui jejaring sosial, serta penggunaan influencer mikro oleh usaha kecil menengah melalui media soaial karena mayoritas penikmat pasar saat ini adalah generasi milenial dan generasi " $Z$ " yang sangat maju akan teknologi (Farahdiba, 2020).

Pada bagian akhir pelatihan, dipaparkan beberapa kekurangan bisnis online yang mungkin sering ditemukan para pelaku usaha, utamanya untuk usaha penjualan pakaian jadi, seperti (i) perbedaan ukuran pakaian yang beragam antara satu pembeli dengan pembeli yang lain, sehingga memperbesar datangnya keberatan dari pihak pembeli, (ii) perbedaan referensi pemilihan warna, serta (iii) keterbatasan penerapan sistem pengembalian barang oleh pemilik usaha.
Tahap 2 : Evaluasi Kegiatan

Praktik Pemasaran Online Menggunakan Media Sosial oleh Peserta

Media sosial memiliki keuntungan dalam kegiatan promosi karena dapat digunakan untuk menyampaikan informasi produk dengan meminimalisir biaya dan tenaga. Dalam kegiatan ini peserta telah mengetahui cara memanfaatkan media sosial berupa Instagram dan facebook sebagai media promosi produk.
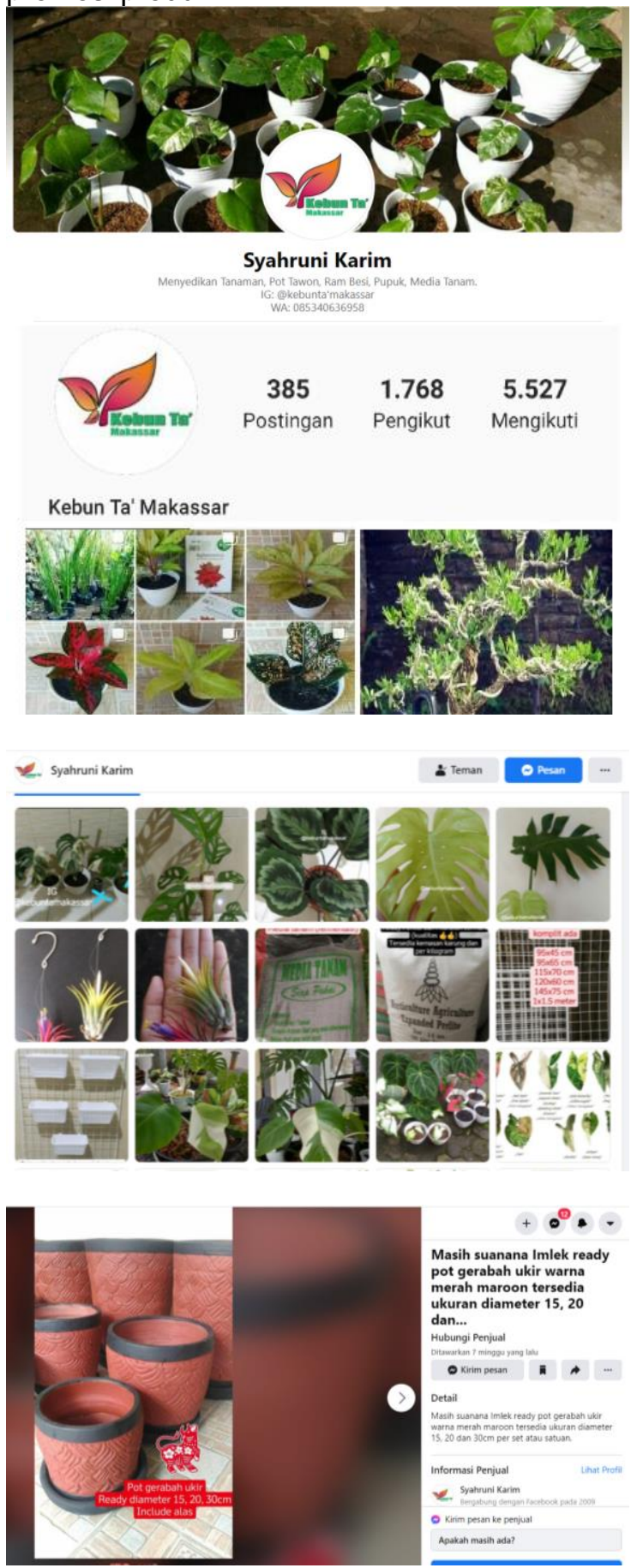

Gambar 3. Promosi produk berupa tanaman hias, media serta wadah tanam pada media Instagram dan Facebook 
Kegiatan promosi produk yang dilakukan oleh peserta melalui penerapan fungsi ads pada media sosial, memberikan potongan harga pada momen tertentu, mengunggah testimoni pada menu story, kumpulan foto, mencantumkan nomor teleepon, serta petunjuk akun produk yang dapat diikuti oleh calon pembeli. Berdasarkan informasi dari peserta yang telah menerapkan pemasaran digital, pemberian potongan harga produk tanaman terbukti dapat meningkatkan angka penjualan.
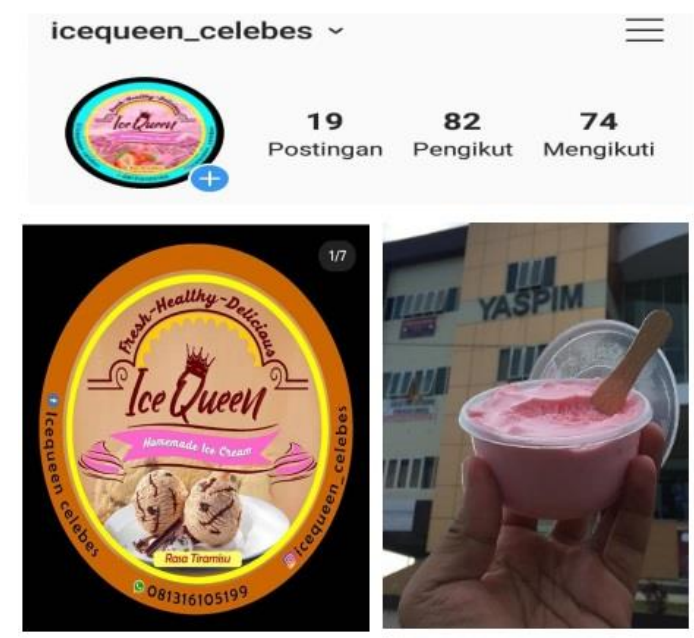

Gambar 4. Promosi produk es krim pada media Instagram

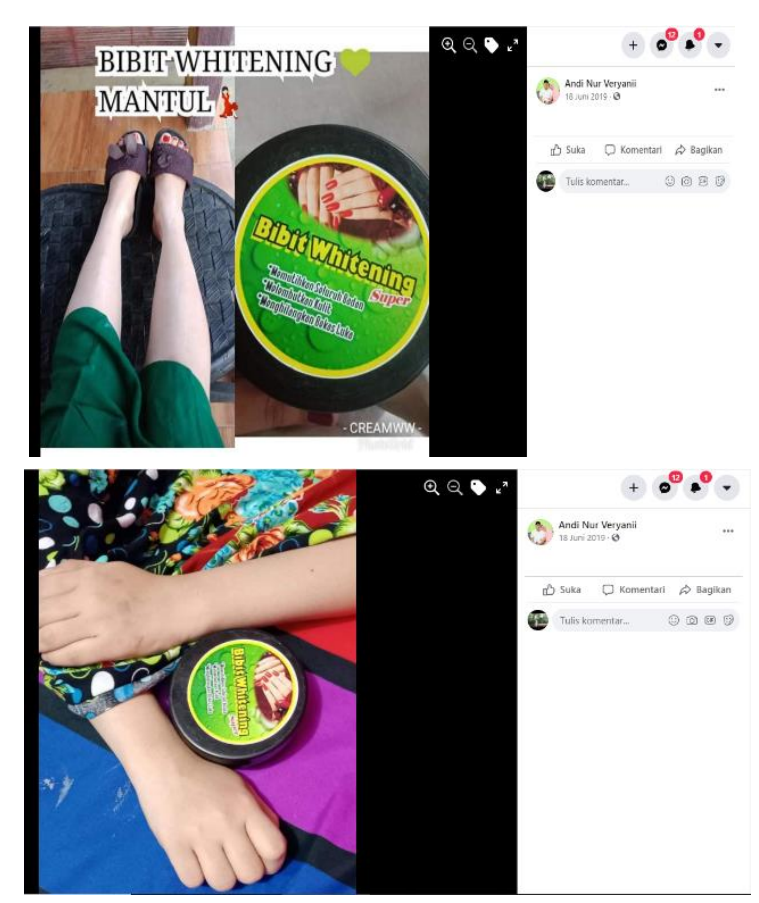

Gambar 5. Promosi produk kosmetik pada media facebook

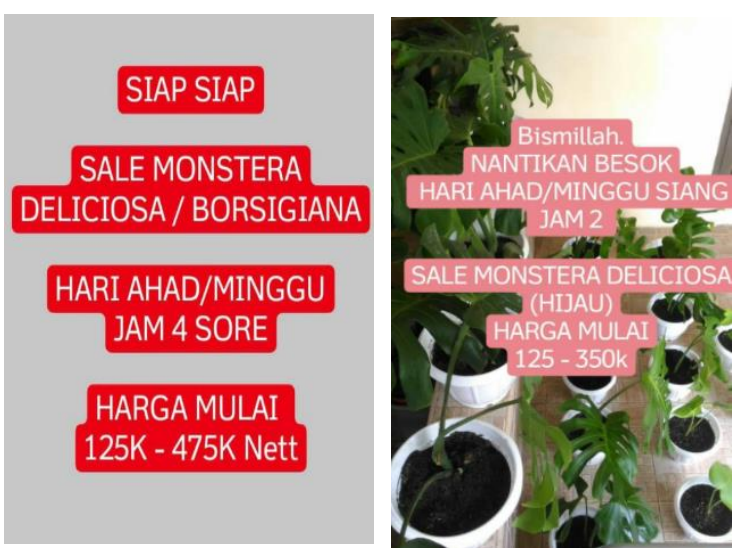

Gambar 6. Promosi melalui potongan harga

\section{Praktik Penggunaan Video Untuk Iklan}

Dari 19 orang peserta, terdapat satu orang peserta yang telah menerapkan video untuk mempromosikan produk yang dijual. Video yang digunakan cukup sederhana, dengan durasi waktu penayangan paling lama 60 detik. Peserta memilih durasi waktu yang singkat dalam melakukan promosi, dengan mempertimbangkan efisiensi waktu yang digunakan calon konsumen untuk menilai produk yang akan dibeli. Berdasarkan pengalaman peserta menggunakan video promosi diketahui satu video produk dapat ditayangkan lebih dari 1.000 kali dalam waktu 24 jam setelah video diupload.

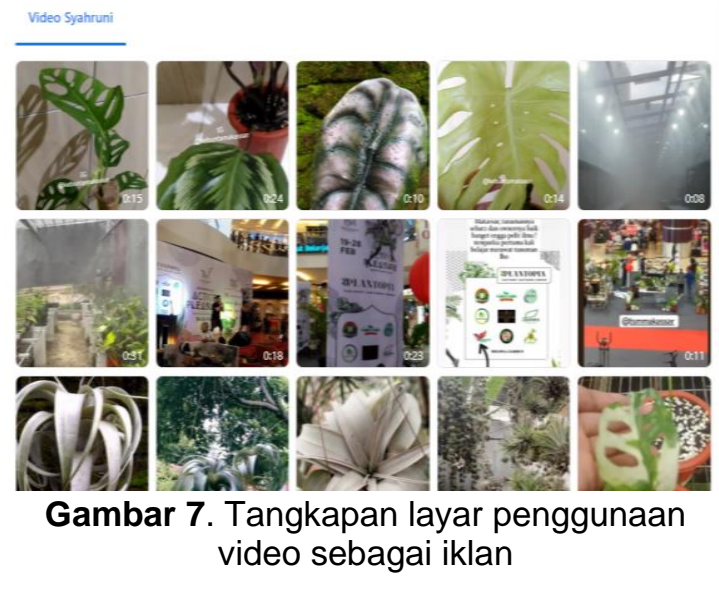

\section{Penilaian Kepuasan Peserta Terhadap Pelatihan yang Diberikan}

Evaluasi pelaksanaan pelatihan dilakukan dengan menyebar angket secara daring maupun langsung kepada peserta pelatihan. Evaluasi mencakup pengukuran reaksi peserta terhadap pelatihan, yang ditinjau dari materi yang dipaparkan, penyeleggaraan kegiatan serta sarana penunjang pelatihan. Hasil pengukuran terlihat pada Tabel 2, yang memperlihatkan terdapat reaksi positif dari peserta yang ditunjukkan pula oleh capaian 
bobot rerata lebih dari $88 \%$.

Tabel 2. Tingkat kepuasan peserta terhadap pelaksanaan pelatihan

\begin{tabular}{|c|c|c|c|}
\hline Elemen & Sub elemen & $\begin{array}{c}\text { Bobot } \\
(\%)\end{array}$ & $\begin{array}{c}\text { Rerata } \\
\text { bobot } \\
(\%)\end{array}$ \\
\hline \multirow[t]{5}{*}{ Materi } & $\begin{array}{l}\text { Sistematika } \\
\text { penyajian } \\
\text { materi }\end{array}$ & 89,5 & 89,3 \\
\hline & $\begin{array}{l}\text { Kejelasan/ } \\
\text { kemudahan } \\
\text { untuk } \\
\text { dipahami }\end{array}$ & 88,1 & \\
\hline & $\begin{array}{l}\text { Kontribusi } \\
\text { dalam } \\
\text { peningkatan } \\
\text { pengetahuan }\end{array}$ & 90,8 & \\
\hline & $\begin{array}{l}\text { Manfaat } \\
\text { dalam } \\
\text { pelatihan }\end{array}$ & 90 & \\
\hline & $\begin{array}{l}\text { Kesesuaian } \\
\text { dengan tujuan } \\
\text { pelatihan }\end{array}$ & 88,2 & \\
\hline \multirow[t]{2}{*}{$\begin{array}{c}\text { Jadwal } \\
\text { kegiatan }\end{array}$} & $\begin{array}{l}\text { Alokasi waktu } \\
\text { kegiatan } \\
\text { selama } \\
\text { pelatihan } \\
\text { berlangsung }\end{array}$ & 88,2 & 89,2 \\
\hline & $\begin{array}{l}\text { Ketepatan } \\
\text { waktu }\end{array}$ & 90 & \\
\hline \multirow[t]{3}{*}{ Sarana } & $\begin{array}{l}\text { Kesesuaian } \\
\text { audio visual } \\
\text { atau alat } \\
\text { peraga }\end{array}$ & 86,8 & 89,2 \\
\hline & $\begin{array}{l}\text { Kualitas audio } \\
\text { visual atau } \\
\text { alat peraga }\end{array}$ & 90 & \\
\hline & $\begin{array}{l}\text { Fasilitas } \\
\text { pelatihan } \\
\text { memadai }\end{array}$ & 90,78 & \\
\hline
\end{tabular}

\section{SIMPULAN DAN SARAN Simpulan}

Kegiatan klinik pemasaran digital dilaksanakan dengan melibatkan 19 orang dosen STKIP Pembangunan Indonesia yang telah memiliki usaha mandiri. Pada kegiatan ini peserta akan diberikan materi mengenai pembuatan web dan media sosial sebagai wadah promosi, penguasaan teknik dasar iklan, dan pemanfaatan video untuk promosi produk.

Peningkatan keterampilan peserta dalam pelatihan ini diketahui dari kemampuan peserta menggunakan web ataupun media sosial sebagai wadah promosi produk. Dari hasil praktik tersebut, sebagian besar peserta menggunakan media sosial Facebook dan Instagram sebagai wadah promosi, dengan mencantumkan secara jelas deskripsi produk, cara pembelian, serta nomor kontak yang dapat dihubungi jika berniat melakukan pemesanan. Selain itu, peserta juga mempraktikkan penggunaan video untuk promosi produk yang berhasil menarik minat calon pembeli.

Dalam pelatihan ini juga dilakukan pengukuran kepuasan peserta terhadap pelatihan yang diberikan. Berdasarkan hasil pengukuran tersebut diperoleh sebanyak $88 \%$ peserta menyatakan puas terhadap pelatihan ini.

\section{Saran}

Besarnya minat dan peluang dosen pemilik usaha untuk mengembangkan usaha skala mikro perlu didukung melalui pendampingan pemasaran digital dengan melibatkan tenaga profesional ataupun penggiat pemasaran digital. Pendampingan tersebut dinilai perlu dilakukan agar dosen dapat menyesuaikan perilaku konsumen yang berubah secara dinamis.

\section{DAFTAR RUJUKAN}

Afrilia AM. (2018). Digital Marketing Sebagai Strategi Komunikasi Pemasaran "Waroenk Ora Umum" Dalam Meningkatkan Jumlah Konsumen. Jurnal Risel Komunikasi. 1(1). 147-157.

Ayuni Q, Hafied C, Aianto. (2019). Pengaruh Penggunaan Media Digital Terhadap Tingkat Penjualan Produk Kuliner Kemasan. Jurnal Penelitian Komunikasi dan Opini Publik. 23(2). 129-141.

Farahdiba D. (2020). Konsep dan Strategi Komunikasi Pemasaran: Perubahan Perilaku Konsumen Menuju Era Disrupsi. Jurnal IImiah Komunikasi Makna. $\quad$ 8(1). 22-28. http://dx.doi.org/10.30659/jikm.v8i1.79 92.

Fauzi, Wulandari, Aprilia S. (2015). Sistem Informasi Penjualan Produk Berbasis Web Pada Chanel Distro Pringsewu. Jurnal Technology Acceptance Model. 4. 41-47.

Fitri RS, Rukun K, Dwiyanti N. (2016). Perancangan dan Implementasi Sistem Informasi Penjualan Komputer dan Accessories Pada Toko Mujahidah Computer Berbasis Web. Jurnal Vokasional Teknik Elektronika dan Informatika. 4(1). 196-211.

Hapsoro BB, Palupiningdyah, Slamet A. (2019). Peran Digital Marketing sebagai Upaya Peningkatan Omset Penjualan Bagi Klaster UMKM di Kota Semarang. Jurnal Pengabdian Kepada Masyarakat. 23(2). 117-120. 
http://dx.doi.org/10.15294/abdimas.v2 3i2.17880.

Lingkan ET, Rapar RW, DMD Warouw. (2015). Komunikasi Pemasaran dan Perilaku Konsumen Di Matahari Departemen Store Mega Trade Center Manado. Jurnal Acta Diurna. 4(4). 1-9.

Malik A, Mulyono SE. (2017). Pengembangan Kewirausahaan Berbasis Potensi Lokal melalui Pemberdayaan Masyarakat. Journal of Nonformal Education and Community Empowerment 1(1). 87101.

Nuhayati Y. (2018). Penerapan Model Kirkpatrick untuk evaluasi diklat teknis substantive materi perencanaan pembelajaran di wilayah kerja provinsi kepulauan Riau. Andragogi Jurnal Diklat Teknis 4(2). 170-187. https://doi.org/10.36052/andragogi.v $\underline{6 \mathrm{i} 2.63}$

Reswana IN. (2017). Strategi Komunikasi Pemasaran Dalam Memasarkan Produk Cemilan Krupuk Singkong Samiler "Samijali" Di UKM Eks Lokalisasi Dolly. Jurnal IkraithHumaniora 1(2). 68-75.

Saputra GW, Ardani IGAKS. (2020). Pengaruh Digital Marketing, Word of Mouth, dan Kualitas Pelayanan Terhadap Keputusan Pembelian. E-Jurnal Manajemen. 9(7). 2596-2620. https://doi.org/10.24843/EJMUNUD.20 20.v09.07.p07.

Sarastuti D. (2017). Strategi komunikasi pemasaran online produk busana muslin queenova. Jurnal Visi Komunikasi 16(1). 71-90. http://dx.doi.org/10.22441/jvk.v16i1.16 45.

Saraswati G. (2017). Pemberdayaan Masyarakat Melalui Wirausaha Kreatif Berbasis Kearifan Lokal. JESA 1(2). 120.

Triyanto WA. (2017). Analisa dan perancangan sistem informasi penjualan online untuk meningkatkan pemasaran produk UMKM kerajinan tas. Indonesian Journal of networking and security $6(3)$. 63-67.

Wardana A. (2015). Strategi Digital Marketing dan Implikasinya Pada Keunggulan Bersaing UKM Di Indonesia. Prosiding Seminar Nasional, Bandung, Indonesia. 327-337. 